\title{
Experimental Investigation of the Performance and Exhaust Emissions of a Spark-Ignition Engine Operating with Different Proportional Blends of Gasoline and Water Ammonia Solution
}

\author{
Sherif Fathy Abd El Fattah ${ }^{1}$, M.F. Ezzat ${ }^{2}$, Mohamed A. Mourad ${ }^{2}$, Medhat Elkelawy ${ }^{3}$, and Ismail M. Youssef ${ }^{2}$ \\ ${ }^{1}$ Mechatronics Department, Faculty of Engineering, MTI University, Egypt \\ ${ }^{2}$ Mechanical Engineering Department, Faculty of Engineering, Minia University, Egypt \\ ${ }^{3}$ Mechanical Power Engineering Departments, Faculty of Engineering, Tanta University, Tanta, Egypt, \\ Emails: miniauniversity@gmail.com, sheriffathy1995@gmail.com, medhatelkelawy@f-eng.tanta.edu.eg,
}

\begin{abstract}
This paper aims to investigate the impact of utilizing different blends of water ammonia solution (WAS) and gasoline fuel (GF) on the exhaust emission and the engine performance of spark ignition (SI) engine and compare the obtained results with a base case where gasoline is used a sole fuel in the SI engine. The results show that the use of ammonia solution as an addition to gasoline fuel increases the overall thermal efficiency. Moreover, blending GF and Was at a ratio of $75 \%$ to $25 \%$ respectively achieved a maximum overall efficiency of $38.96 \%$ at the maximum load condition. In addition, the specific fuel consumption of the previously mentioned blend is reduced significantly compared to the base case. However, the results displayed that adding WAS leads to an upsurge in the $\mathrm{CO}, \mathrm{HC}$, and NOx levels.
\end{abstract}

Keywords: Spark Ignition Engine; Gasoline; Ammonia; Combustion; Engine Emissions

\section{INTRODUCTION}

Vehicles are widely regarded as the biggest contributor to both the energy crises and greenhouse gas emissions. They account for 60.5 percent of world petroleum usage in the United States, for example, and are predicted to boost global $\mathrm{CO} 2$ emissions by $30-50$ percent by 2050 [1]. Several alternative fuels-vehicle combinations are being considered for replacement of the internal combustion engine (ICE) vehicles to reduce greenhouse gas (GHG) emissions and the dependence on fossil fuels. Ammonia is an encouraging, carbon-free fuel. However, further implementation of ammonia as a fuel in the near future is possible if extensive research is conducted. Although ammonia is currently extracted from fossil fuels, the greenhouse gas footprint of ammonia can almost be eliminated in the future if it is generated from renewable sources using green electricity $[2,3]$.

Ammonia, in particular, has a range of properties that need further study. Compared to other fuels, it ignites and burns poorly and is toxic and corrosive, making safe handling and storage necessary. Burning ammonia may also lead to higher NOx emissions unless it is regulated either after treatment or by optimizing the method of combustion [4]. Showing interest, internal combustion engines (ICE) transform heat energy into mechanical work after the internal combustion of any carbon fuel $[5,6]$. The fuel charge can be supplied either via the injection before the intake ports of the cylinder or directly within the combustion chamber, known as direct injection (DI) engines $[7,8]$.

Air and fuel combustion occur whether by supplying an ignition source, such as a spark in a Spark Ignition (SI) engine or by compression when the fuel's auto-ignition temperature is reached, recognized as the CI engine [9, 10]. Combustion has always been the main source of energy for human and industrial activities across the globe, and in the past, efforts were made to reduce GHG emissions through increased efficiency of combustion equipment [11]. Combusting new fuels for both the stationary engines and the ICEs are being investigated [12-14]. Combustion of which makes a significant contribution to air pollution by emitting significant amounts of soot, carbon dioxide (CO2), and nitrogen oxides (NOx), thereby devoting to the greenhouse impact $[15,16]$.

For several years, generators are utilized to generate power by burning carbon fuels; however, these fuels produced harmful emissions, and a potential alternative may occur in the use of carbon-free fuels such as ammonia. One alternative is to propose a novel electric generator that works on ammonia. Regrettably, because these generators are generally designed to operate with other forms of fuel, some issues arise with the utilization of ammonia to run these generators.

Arda and Dincer [17] discuss these issues and other reasonable alternatives by examining the mixture of ammonia with other fuel types. Ammonia is regarded as an alternate and green fuel since it contains hydrogen and nitrogen; when it burns completely, it produces nitrogen and water, avoiding any $\mathrm{CO} 2$ emissions that emit from conventional ICEs running on fossil fuels [18]. However, achieving any significant reduction in the harmful emissions from ammonia ICEs compared to conventional ICEs is inadequate criterion to promote the use of ammonia ICEs, and thermal efficiency evaluation for ammonia ICEs should also be considered. There are several difficulties associated with the usage of ammonia, owing to the sluggish speed of the burning flames, and ammonia's low temperatures of flames. Therefore, a combustion enhancer is necessary to 
maintain a suitable ICE performance along with the mitigation of the harmful emissions [19, 20]. Additionally, ammonia high autoignition temperature complicates its use in SI engines, since it results in a lower temperature of combustion and a reduced engine power [21].

Regardless of the previous mentioned shortcomings, ammonia can highly contribute to a better environment which promotes it as a potential candidate to be a suitable fossil fuel alternative shortly. Additionally, its potential to keep hydrogen should be considered as the cost of keeping hydrogen is three times that of storing ammonia, making it a safe and efficient method of storing hydrogen [17]. The generators have been categorized in the literature according to engine ignition type. $\mathrm{CI}$ and SI generators are the two most common types employed in these generators, as they use distinct processes to ignite and consume the fuel. Each type has multiple merits and demerits when contrasted to the other types. Numerous studies are carried out on the usage of ammonia-gasoline combinations or ammonia as a sole fuel with hydrogen a combustion enhancer in SI engines [17, 22-25].

Experimental results demonstrated that using water ammonia solution-gasoline blended fuels mitigated the engine performance. The different investigations proved that mixing WAS with GF increased the overall thermal efficiency and brake power. Nonetheless, a noticeable decrease in the brake and specific fuel consumption of the engine is observed. However, $\mathrm{HC}$ and $\mathrm{CO}$ emission levels are increased with the augmentation of the WAS in the blend due to the incomplete combustion of the fuel mixture [16]. It can be understood from the present literature review that mixing WAS with GF in SI engine improves engine performance and increases harmful emissions.

The world is currently facing two major issues, namely the scarcity of the fossil fuel resources, and the global warming, which originates from the extensive combustion of fossil fuels and releasing greenhouse gases such as $\mathrm{CO}$. Therefore, utilizing alternative fuels, particularly carbon-free fuels such as ammonia and hydrogen, that can replace the fossil fuel ones is mandatory. The objectives of this study are as follows:

1. To Evaluate the effect of using different proportional blends of WAS (secondary fuel) and GF on the SI engine performance.

2. To Assess the effect of using different proportional blends of WAS (secondary fuel) and GF on the SI exhaust emisions.

3. To compare the results of the ICE performance, represented in thermal efficiency, for the ICE that uses different proportional WAS-GF blends to ICE utilizing only GF.

4. To compare the obtained exhaust emissions, represented in $\mathrm{CO}_{2}, \mathrm{HC}, \mathrm{CO}$ and $\mathrm{NOx}$ released from the ICE during the utilization of different proportional WAS-GF blends to the emissions emitted from ICE that utilizes only GF.

\section{EXPERIMENTAL METHODOLOGY DESCRIPTION}

\subsection{Engine specification}

The engine utilized in this study is a single cylinder four stroke air cooled engine with cubic capacity of $212 \mathrm{~cm}^{3}$, and a maximum output power of $2.5 \mathrm{~kW}$ at $3000 \mathrm{rpm}$. The engine is directly coupled to AC generator with rated output capacity of $2.5 \mathrm{~kW}, 220 \mathrm{~V}, 50 \mathrm{~Hz}$. The major specifications of the engine are given in Table 1.

TABLE 1: ENGINE SPECIFICATION

\begin{tabular}{|l|c|}
\hline Type & Single Cylinder, Four Stroke \\
\hline Displacement $\left(\mathrm{cm}^{3}\right)$ & 212 \\
\hline Bore x Stroke $(\mathrm{mm})$ & $70 \times 54$ \\
\hline Method of Cooling & Forced Air Cooling \\
\hline Model Designation & Lincon-Ge3500(D)-Lc7000 \\
\hline Compression Ratio & $8.5: 1$ \\
\hline Rated Output Power & $2.5 \mathrm{~kW}$ at 3000 rpm \\
\hline Fuel Delivery System & Conventional Carburetor \\
\hline
\end{tabular}

\section{Electric load board:}

The electric load board was used as a variable electric loads. It consists of ( 2 columns * 5 rows) of lamps. The power of each lamp is 500 watts. The electric current generated is consumed through illuminating a number of lighting bulbs, as shown in (). The load can be controlled by switching on or off each column.

\subsection{Experimental apparatus and test procedure}

The generator's produced electrical power was evaluated using an electrical digital voltmeter and a digital $\mathrm{A}$ meter to determine the engine load. Exhaust gases such as $\mathrm{CO}, \mathrm{CO}_{2}$, $\mathrm{NOx}, \mathrm{O}_{2}$, and $\mathrm{HC}$ are quantified using a commercial gas analyzer device, model "SDK-HPC500 via a sensor that is placed in a designed sheet metal box right after the muffler to avoid the existence of any residue of water vapor. demonstrates the schematic of the investigated engine along with the instrumentation devices.

displays the engine setup in the lab during engine loading. During this investigation, various fuel samples were investigated experimentally. Base gasoline (92 octanes) was obtained from a local fuel station. A local chemicals supplier provided the WAS with a purity of $25 \%$. For the testing purpose, gasoline has a lower heating value of $42.45 \mathrm{MJ} / \mathrm{kg}$. WAS is estimated to have a heating value of $2.69 \mathrm{MJ} / \mathrm{kg}$. Gasoline has a density of $700-765 \mathrm{Kg} / \mathrm{m}^{3}$, while ammonia solution has a density of $910 \mathrm{Kg} / \mathrm{m}^{3}$. Five test combinations were prepared by mixing base gasoline with WAS as described in Table 2. The blended fuels were prepared immediately before the start of the experiment to ensure that the fuel mixture is homogeneous. 
TABLE 2 : Gasoline / Water Ammonia Solution Fuel Blends

\begin{tabular}{|c|c|c|c|}
\hline Blends & Gasoline \% & WAS\% & Identification \\
\hline 1 & 100 & - & Gasoline \\
\hline 2 & 95 & 5 & WAS 5\% \\
\hline 3 & 90 & 10 & WAS 10\% \\
\hline 4 & 85 & 15 & WAS 15\% \\
\hline 5 & 80 & 20 & WAS 20\% \\
\hline 6 & 75 & 25 & WAS 25\% \\
\hline
\end{tabular}

TABLE 3: Uncertainties Of Test Set Up Measurements

\begin{tabular}{|l|l|}
\hline Measurement & Accuracy \\
\hline BTE & Max. 2.4\% \\
\hline BSFC & Max. 2.4\% \\
\hline Calculated results & Uncertainly \\
\hline $\mathrm{CO}_{2}$ & $\pm 0.1 \%$ \\
\hline $\mathrm{CO}$ & $\pm 0.1 \%$ \\
\hline $\mathrm{HC}$ & $\pm 1 \mathrm{ppm}$ \\
\hline NOx & $\pm 1 \mathrm{ppm}$ \\
\hline
\end{tabular}

The engine was started by hand cranking with a recoil starter rope. Just after the engine is started, the choke was turned into a fully open position. The engine was permitted to keep running for a time ranging from 10-15 minutes for warming up and achieving steady condition. The testing was performed at a consistent speed rate of $3000 \mathrm{rpm}$ and with the following load variations: no load, $0.5 \mathrm{~kW}, 1 \mathrm{~kW}, 1.50 \mathrm{~kW}, 2 \mathrm{~kW}$, and $2.5 \mathrm{~kW}$. Then, different WAS-GF blends were supplied to the engine consecutively under the same test conditions. Once the engine's operating condition is stabilized, exhaust emission constituents were recorded. Before switching the operation of the engine to another fuel mixture, it was permitted to keep it running for a sufficient time to burn any fuel remaning from the past experiment.

\section{III.RESULTS AND DISCUSSION}

\subsection{Ammonia solution-gasoline blends experiments}

It is well established that ammonia derived from renewable energy sources will provide a green-originated carbon free fuel [11]. To improve combustion, the blends of ammonia solution and GF were used to optimize the engine's performance [16]. Ammonia has enormous promise as a substitute for petroleumbased fuels. When combined with hydrocarbon fuels, ammonia can be utilized as an alternative fuel to power current ICE. Similar to Methanol and gasoline fuel mixes, these types of mixtures c/an be utilized to market ammonia as an alternative fuel. The properties of the fuels utilized in this study are given in Table 4. The effect of changing the proportions of WAS to GF on engine fuel consumption, thermal efficiency of the enegine and exhaust emissions temperature and composition are discussed in the following sections.

\section{A. Fuel consumption and specific fuel consumption $(F C \& S F C)$}

The effect of changing WAS proportion in the G-WAS blend on the engine FC at different loads is presented in Fig. 3. There is no discernible difference between gasoline and different GWAS blends in terms of FC. In general, the blend with $75 \% \mathrm{G}$ and $25 \%$ WAS displays the least FC at the different load conditions. This is maybe due to the presence of oxygen in the fuel blend, which enhances combustion efficiency.

SFC is characterized as the fuel consumption for each produced power unit. SFC data at various engine loads are shown in Fig. 4. The fact that the SFC reduced as the engine load grew for all tested fuels might be attributed to the fact that the rate of the generated power is greater than the rate of increase of the fuel consumption. SFC values for G75-WAS 25 fuel were lower than those for gasoline fuel at maximum load condition. This is because G75-WAS25 is an oxygenated fuel, which results in improved combustion and thus lower SFC values.

TABLE 4 : Properties of The Utilized Fuels

\begin{tabular}{|c|c|c|}
\hline Fuel property & Gasoline & $\begin{array}{c}\text { Water Ammonia } \\
\text { Hydroxide }\end{array}$ \\
\hline Chemical formula & $\mathrm{C}_{8} \mathrm{H}_{18}$ & $\mathrm{NH}_{4} \mathrm{OH}$ \\
\hline Density $\left(\mathrm{kg} / \mathrm{m}^{3}\right)$ & $700-760$ & 910 \\
\hline Stoichiometric air/fuel ratio & 14.6 & \\
\hline Low calorific value (MJ/Kg) & 42.45 & 2.69 \\
\hline High calorific value $(\mathrm{MJ} / \mathrm{Kg})$ & 46.6 & \\
\hline Boiling Point $(\mathrm{deg} \mathrm{C})$ & $30-220$ & 310 \\
\hline Freezing Point $(\mathrm{deg} \mathrm{C})$ & -57 & \\
\hline Research Octane number & $80-98$ & \\
\hline Motor Octane number & $81-84$ & \\
\hline Flammability limit & $1.47-7.6$ & \\
\hline Viscosity (at $\left.20^{\circ} \mathrm{C}\right)(\mathrm{CP})$ & 0.29 & \\
\hline
\end{tabular}

\section{B. Thermal efficiency of the engine $\left(\eta_{t h}\right)$}

As well known, engine thermal efficiency is defined as the ratio of power generated to the energy contained in the fuel burned. It quantifies the effectiveness of combustion within the engine cylinder [26]. The comparison of the thermal efficiency for the examined blends is shown in Fig. 5. At the engine speed of $3000 \mathrm{rpm}$, the thermal efficiencies for the blends with WAS $15 \%$, WAS $20 \%$, WAS $25 \%$ at an engine output power of 0.5 $\mathrm{kW}$ are increased by $8.9 \%, 19.1 \%$, and $30.9 \%$, respectively, compared to the thermal efficiency of the engine running on pure gasoline.

Moreover, the engine thermal efficiencies at the highest possible engine power $(2.5 \mathrm{~kW})$ for WAS $15 \%$, WAS $20 \%$, WAS $25 \%$ are found to be higher than that of the pure gasoline engine by $16 \%, 28.2 \%$, and $38.9 \%$, respectively. 


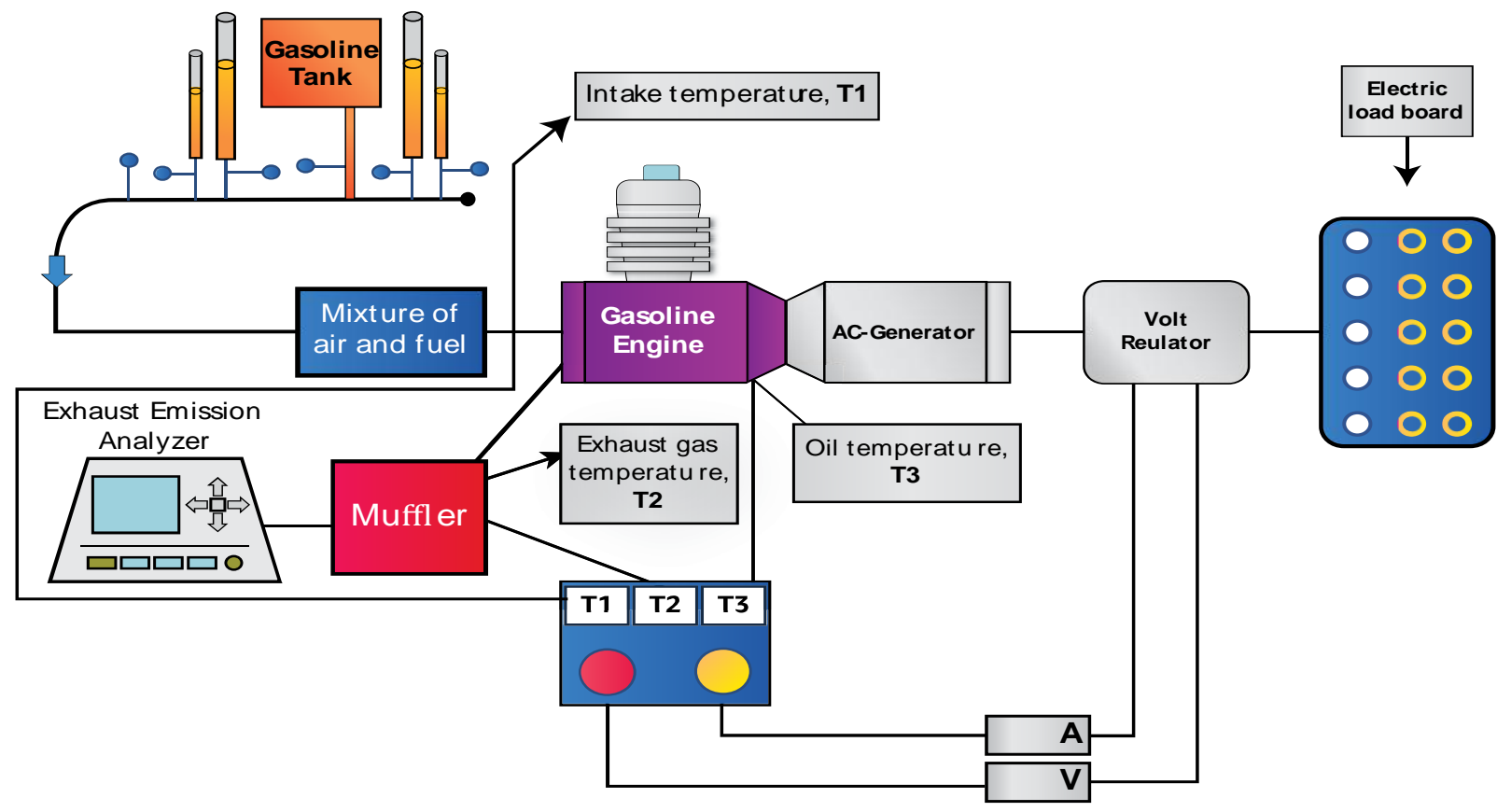

Fig. 1: Schematic of the investigated engine coupled with the electric generator along with the different instrumentation devices.



Fig. 2: Experimental setup direct phots



Fig. 3: Comparison of fuel consumption for different gasoline/WAS blends and its variation with engine power at constant speed of $3000 \mathrm{rpm}$.

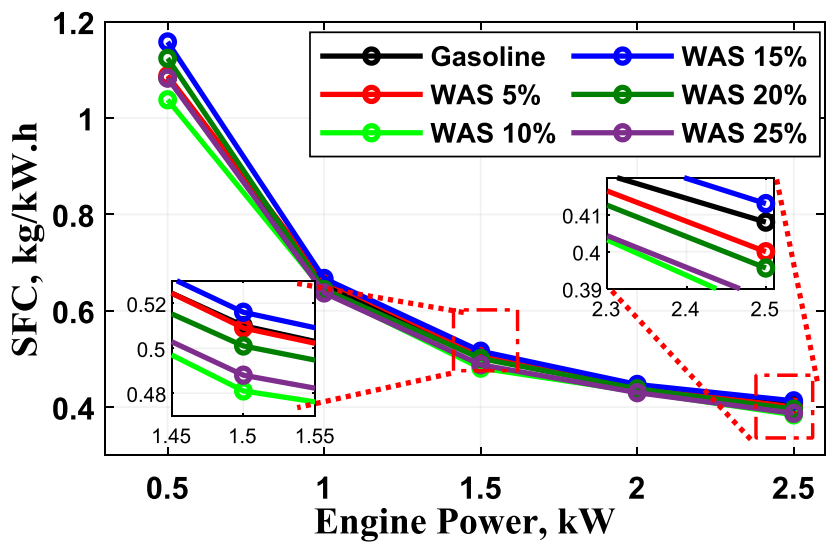

Fig. 4: Comparison of Specific fuel consumption for different gasoline/WAS blends at various engine power at constant speed $3000 \mathrm{rpm}$. 


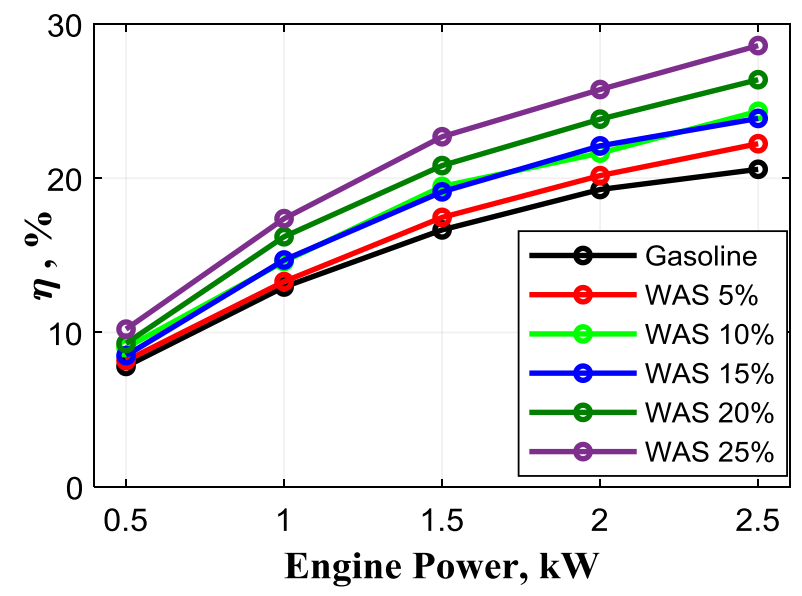

Fig. 5: Comparison of overall Efficiency for different gasoline/WAS blends at different power of an engine operating at a constant speed of $3000 \mathrm{rpm}$.

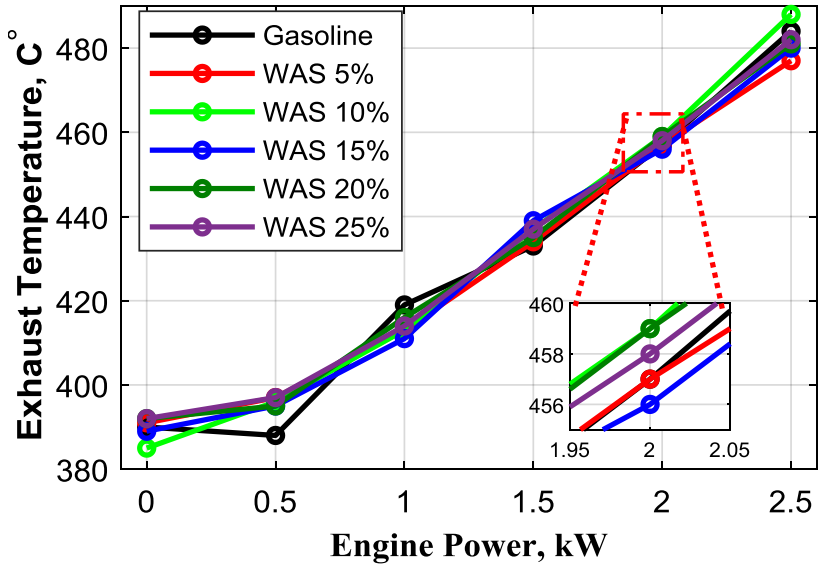

Fig. 6: Comparison of the exhaust temperature for different gasoline/WAS blends at various power of an engine running at a constant speed of $3000 \mathrm{rpm}$.

It is observed that the blend with $25 \%$ of WAS provides a higher thermal efficiency compared to GF and the other blends at different engine output power, especially at high engine power of $2.5 \mathrm{~kW}$. The main reason for this behavior is that the blend with $25 \%$ of WAS is already consuming less fuel compared to the other blends at the same output powe. Therefore, the engine input energy for the blend with $25 \%$ of WAS is lower than the engine input energy of the other blends.

\section{Exhaust Gas Temperature (EGT)}

The EGT demonstrates the efficient utilization of heat energy from the fuel. A greater value is unpleasant because it reduces the fuel's heat energy's conversion to useful work [27]. Overall, WAS combinations have a reduced EGT than standard gasoline. Thus, as anticipated, as the quantity of ammonia in the combustion chamber increases, the combustion temperature values may decrease due to the sluggish speed of combustion and ammonia's lower temperature of the flames. Incomplete combustion can occur at low cylinder temperatures [28].

\subsection{Emission characteristics}

\section{A. Effect on CO emissions}

Fig. 7 illustrates the influence of utilizing different blends of WAS-GF on the engine $\mathrm{CO}$ emissions and the results are compared to $\mathrm{CO}$ emission from pure gasoline engine. For the gasoline and the other blends, the engine $\mathrm{CO}$ emissions decrease with the increase of the engine power. However, the utilization of the WAS based blends show higher levels of $\mathrm{CO}$ compared to the GF. A potential reason for the higher $\mathrm{CO}$ emissions is related to the possibility of incomplete combustion of the WAS owing to the reduced combustion temperature of ammonia, particularly at low loads [29]. Moreover, the addition of the ammonia fuel to the GF reduces the pressure and temperature of combustion leading to an upsurge in the $\mathrm{CO}$ emissions [30].

It can be seen that $\mathrm{CO}$ emissions at low engine load of $0.5 \mathrm{~kW}$ achieve a higher level of increase compared to pure gasoline fuel, especially with supplying WAS $25 \%$, WAS $20 \%$, and WAS $15 \%$, respectively, to the engine. For instance, using WAS 15\%, WAS $20 \%$, and WAS $25 \%$ blends at an engine power of $0.5 \mathrm{~kW}$ and $3000 \mathrm{rpm}$ result in an augmentation in the $\mathrm{CO}$ emissions of about $7.3 \%, 8.46 \%$, and $9.6 \%$, respectively compared to GF. Nonetheless, at high engine load of $2.5 \mathrm{~kW}$, the $\mathrm{CO}$ emissions for the same blends increase by $3.9 \%, 5.8 \%$, and $7 \%$, respectively. Accordingly, it can be concluded that the addition of WAS into gasoline is more enviromental for getting lower emissions at high engine loads.

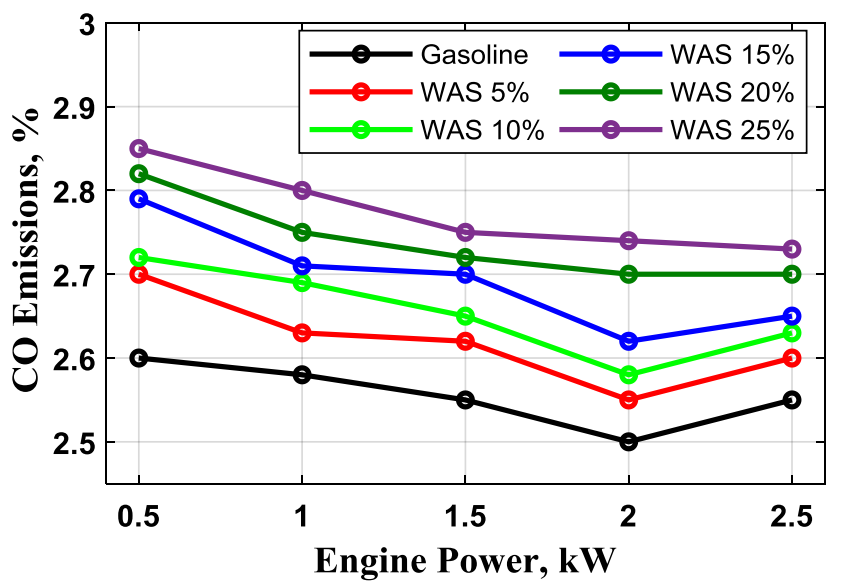

Fig. 7: Comparison of Carbon Monoxide emissions for different gasoline/WAS blends at various engine power and constant speed of $3000 \mathrm{rpm}$.

\section{B. Carbon dioxide $\left(\mathrm{CO}_{2}\right)$ emission}

$\mathrm{CO}_{2}$ occurs in the atmosphere and carbon is a main component in any fossil fuel composition. Thus, the combustion process of the fossil fuels encounters the release of $\mathrm{CO}_{2}$. Fig. 8 shows the effect of utilizing different proportions of WAS and $\mathrm{GF}$ on $\mathrm{CO}_{2}$ emissions. In the instance of $\mathrm{CO}_{2}$, the impact of WAS on the amount of $\mathrm{CO}_{2}$ released from the engine is determined to be minimal. 
The variations in the concentration of $\mathrm{CO}_{2}$ are found not to be larger than 18 percent after the combination of WAS with GF. It is observed that the ideal ratios that provide the lowest $\mathrm{CO} 2$ emissions are achieved by adding WAS to the GF at percentages of $20 \%$ and $15 \%$, respectively. Whereas the percentage of $\mathrm{CO} 2$ emission also increases with WAS 5\% WAS10\%, and WAS 25\% blends. At the start of the combustion, the percentage was reduced due to the insufficient mixing of WAS with gasoline, as ammonia is a polarized molecule and gasoline is a nonpolarized molecule with a long carbon chain. This decreases ammonia's solubility in gasoline [31], and consequently the percentage of $\mathrm{CO}_{2}$ gradually decreased with WAS15\%, WAS20\%, and WAS25\%, respectively. Fig. 8 illustrates the variations of $\mathrm{CO}_{2}$ emissions at various engine power. $\mathrm{CO}_{2}$ concentrations are observed to increase with any augmentation in engine power.

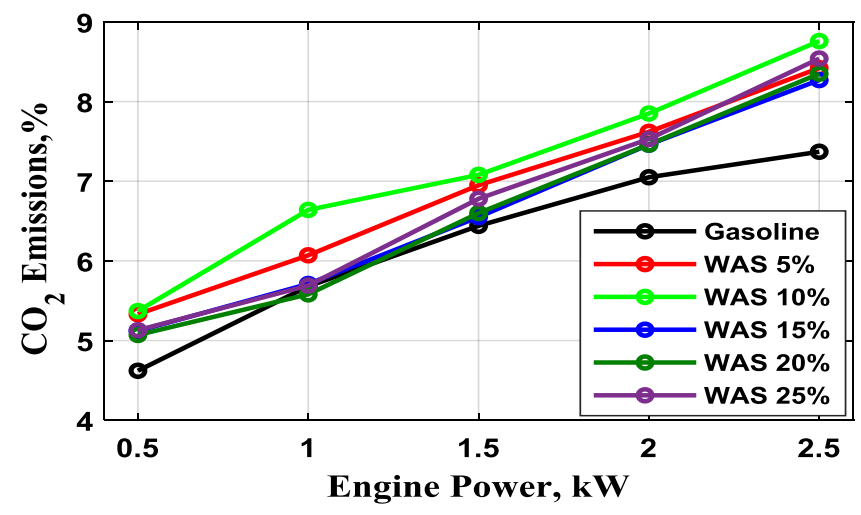

Fig. 8: Variation of the $\mathrm{Co} 2$ emissions with engine power for different gasoline/WAS blends at engine constant speed of $3000 \mathrm{rpm}$.

\section{Hydrocarbons (HC) emission}

HC productions, which are mainly determined by unburned mixtures, occur on the outskirts of reaction regions [32]. At low loads, leaner mixture and lower combustion temperature increase $\mathrm{HC}$ emission caused by flame quenching on the chamber walls. Fig. 9 shows that the emissions of HC released from the use of different WAS blends are higher than that of pure gasoline. The combustion pressure and temperature are reduced, leading to an increase in the $\mathrm{CO}$ and $\mathrm{HC}$ emissions [30].

Fig. 9 shows clearly that the variation of $\mathrm{HC}$ emissions with the engine power for the different WAS-GF blends. It can be noted that $\mathrm{HC}$ emissions increase with engine load. Nonetheless, it decrease with the increase of the WAS percentage in the fuel blend, particularly at low engine power. At the low engine power of $0.5 \mathrm{~kW}$, the increase of the $\mathrm{HC}$ emissions for WAS $15 \%$, WAS $20 \%$, and WAS $25 \%$, are found to be $13.8 \%, 8.3 \%$, and $6.36 \%$, respectively, compared to the gasoline base case. At high engine power of $2.5 \mathrm{~kW}, \mathrm{HC}$ emissions of WAS $25 \%$ are observed to surge up by $10.58 \%$, compared to base gasoline case.

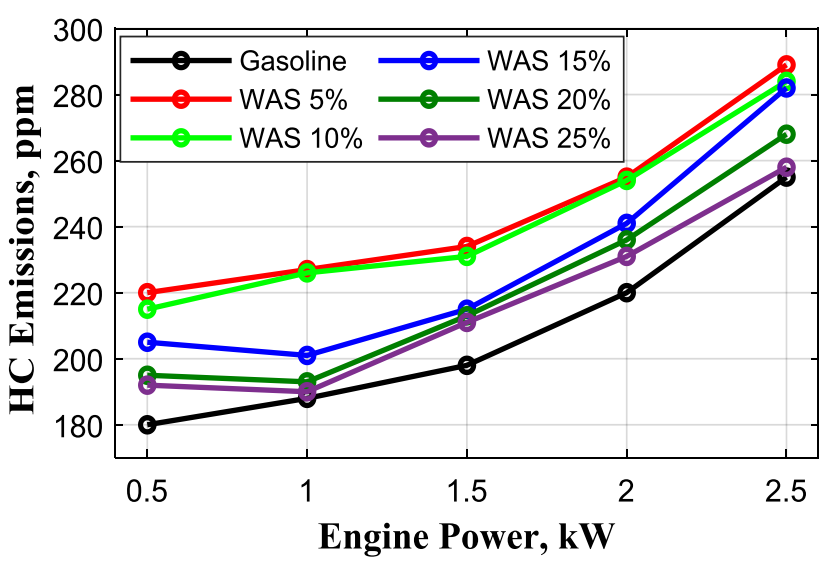

Fig. 9: Variation of the $\mathrm{HC}$ emissions with engine power for different gasoline/WAS blends at engine constant speed of $3000 \mathrm{rpm}$.

\section{Nitrogen oxides (NOx) emissions}

As illustrated in Fig. 10, NOx emissions increase with increasing engine power for all the blended fuels. NOx generation requires a greater combustion temperature, a prolonged residence time at that temperature, and oxygen enrichment in the reaction areas. When engine load increases, the combustion temperature may increase, leading to increased NOx emissions [33]. Furthermore, the increase in the NOx emissions may also attributed to the increase in the WAS percentage in the fuel blends, which consequently increases the percentage of nitrogen in the mixture and increases the chance of forming NOx in the released exhaust.

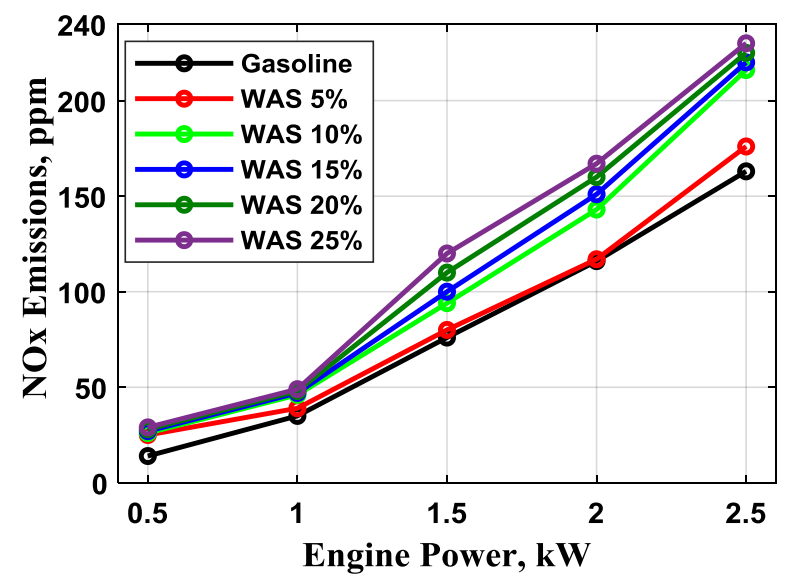

Fig. 10: Variation of the NOx emissions with engine power for different gasoline/WAS blends at engine constant speed of $3000 \mathrm{rpm}$.

\section{CONCLUSION}

The impacts of adding different proportions of WAS to GF on the released emissions and engine performance were explored experimentally via a single cylinder air cooled and naturally aspirated test engine. The percentage of the added WAS varied from $5 \%$ to $25 \%$ by volume basis in the fuel blend that mainly contains commercial gasoline with 92 octane number The primary findings of the current study are as follows:

1. The obtained results indicate that the thermal efficiency of 
the engine that operates with different WAS-GF blends [4] achieves higher values compared to the thermal efficiency of the engine which runs only on GF. For instance, using [5] $25 \%$ of WAS in the blend attains an upsurge of $38.9 \%$ in the engine thermal efficiency.

2. Utilization of gasoline accomplishes the lowest emissions of $\mathrm{CO}, \mathrm{CO} 2, \mathrm{HC}$ and NOx. Moreover, the maximum [6] improvement in $\mathrm{CO}$ emissions using WAS blends was obtained when a low percentage of WAS (WAS 5\%) is utilized at an engine power of $3 \mathrm{~kW}$. On the contrary, HC and $\mathrm{CO} 2$ emissions record the lowest values, almost [7] comparable to gasoline base case, when a high percentage of WAS (WAS 25\%) is utilized at an engine power of 0.5 $\mathrm{kW}$.

3. The FC and SFC using WAS-GF blends were generally reduced compared to the pure gasoline base case, expressly when WAS 25\% and WAS 15\% are supplied to the engine. It can be also noticed that the SFC of WAS-GF blends is significantly reduced with the augmentation in the engine power.

Carrying out dynamic analysis using different driving cycles should be considered to evaluate the performance and exhaust emission for the engine that operates with WAS-GF blend. Furthermore, the current research can be extended to examine the use of liquid ammonia instead of the WAS and investigates its influence on the performance and exhaust emission of the SI engine is

\section{List of abreviations}

\begin{tabular}{ll} 
WAS & Water Ammonia Solution \\
\hline $\mathrm{GF}$ & Gasoline Fuel \\
\hline $\mathrm{CO}$ & Carbon Monoxide \\
\hline $\mathrm{CO}_{2}$ & Carbon Dioxide \\
\hline $\mathrm{HC}$ & Hydrocarbon \\
\hline $\mathrm{NO} \times$ & Nitrogen oxides emissions \\
\hline $\mathrm{SI}$ & Spark Ignition \\
\hline $\mathrm{DF}$ & Dual Fuel \\
\hline FC & Fuel Consumption \\
\hline $\mathrm{SFC}$ & Specific Fuel Consumption \\
\hline EGT & Exhaust Gas Temperature \\
\hline $\mathrm{GM}$ & Generator Motor \\
\hline
\end{tabular}

\section{REFERENCES}

[1] I. Dincer, and M. F. Ezzat, "5.24 Sectoral Energy and Exergy Management," Comprehensive Energy Systems, I. Dincer, ed., pp. 896-926, Oxford: Elsevier, 2018.

[2] N. Ash, and T. Scarbrough, "Sailing on solar: Could green ammonia [17] decarbonise international shipping," Environmental Defense Fund: London, UK, 2019.

[3] H. Kim, K. Y. Koo, and T.-H. Joung, "A study on the necessity of integrated [18] evaluation of alternative marine fuels," Journal of International Maritime Safety, Environmental Affairs, and Shipping, vol. 4, no. 2, pp. 26-31, 2020.
A. Valera-Medina, H. Xiao, M. Owen-Jones, W. I. David, and P. Bowen, "Ammonia for power," Progress in Energy and Combustion Science, vol. 69, pp. 63-102, 2018.

M. Elkelawy, A. E. Kabeel, E. A. El Shenawy, H. Panchal, A. Elbanna, H. A.-E. Bastawissi, and K. K. Sadasivuni, "Experimental investigation on the influences of acetone organic compound additives into the diesel/biodiesel mixture in CI engine," Sustainable Energy Technologies and Assessments, vol. 37, pp. 100614, 2020/02/01/, 2020.

M. Elkelawy, H. Alm-Eldin Bastawissi, E. A. El Shenawy, M. Taha, H. Panchal, and K. K. Sadasivuni, "Study of performance, combustion, and emissions parameters of DI-diesel engine fueled with algae biodiesel/diesel/n-pentane blends," Energy Conversion and Management: X, vol. 10, pp. 100058, 2021/06/01/, 2021.

M. Elkelawy, H. Bastawissi, S. C. Sekar, K. Karuppasamy, N. Vedaraman, K. Sathiyamoorthy, and R. Sathyamurthy, Numerical and experimental investigation of ethyl alcohol as oxygenator on the combustion, performance, and emission characteristics of diesel/cotton seed oil blends in homogenous charge compression ignition engine, 0148-7191, SAE Technical Paper, 2018.

[8] M. ElKelawy, H. A.-E. Bastawissi, E.-S. A. El-Shenawy, H. Panchal, K Sadashivuni, D. Ponnamma, M. Al-Hofy, N. Thakar, and R. Walvekar, "Experimental investigations on spray flames and emissions analysis of diesel and diesel/biodiesel blends for combustion in oxy-fuel burner," AsiaPacific Journal of Chemical Engineering, vol. 14, no. 6, pp. e2375, 2019.

A. M. Elzahaby, M. Elkelawy, H. A.-E. Bastawissi, S. M. El_Malla, and A M. M. Naceb, "Kinetic modeling and experimental study on the combustion, performance and emission characteristics of a PCCI engine fueled with ethanol-diesel blends," Egyptian Journal of Petroleum, vol. 27, no. 4, pp. 927-937, 2018/12/01/, 2018.

[10] H. A. E. Bastawissi, M. Elkelawy, H. Panchal, and K. Kumar Sadasivuni, "Optimization of the multi-carburant dose as an energy source for the application of the HCCI engine," Fuel, vol. 253, pp. 15-24, 2019/10/01/, 2019.

[11] C. Lhuillier, P. Brequigny, F. Contino, and C. Rousselle, Combustion characteristics of ammonia in a modern spark-ignition engine, 0148-7191, SAE Technical Paper, 2019.

[12] S. C. Sekhar, K. Karuppasamy, R. Sathyamurthy, M. Elkelawy, H. A. E. D. Bastawissi, P. Paramasivan, K. Sathiyamoorthy, and P. Edison, "Emission analysis on compression ignition engine fueled with lower concentrations of Pithecellobium dulce biodiesel-diesel blends," Heat Transfer-Asian Research, vol. 48, no. 1, pp. 254-269, 2019.

[13] M. Elkelawy, S. E.-d. H. Etaiw, M. I. Ayad, H. Marie, M. Dawood, H. Panchal, and H. A.-E. Bastawissi, "An enhancement in the diesel engine performance, combustion, and emission attributes fueled by diesel-biodiesel and 3D silver thiocyanate nanoparticles additive fuel blends," Journal of the Taiwan Institute of Chemical Engineers, vol. 124, pp. 369-380, 2021/07/01/, 2021.

[14] M. Elkelawy, S. E.-d. H. Etaiw, H. A.-E. Bastawissi, H. Marie, A. M. Radwan, M. M. Dawood, and H. Panchal, "WCO biodiesel production by heterogeneous catalyst and using cadmium (II)-based supramolecular coordination polymer additives to improve diesel/biodiesel fueled engine performance and emissions," Journal of Thermal Analysis and Calorimetry, 2021/06/27, 2021.

[15] M. Elkelawy, S. E. Etaiw, H. Alm Eldin, H. Marie, A. Elbanna, H. Panchal, K. k. Sadasivuni, and H. Bhargav, "Study of Diesel-Biodiesel Blends Combustion and Emission Characteristics in a CI Engine by adding Nanoparticles of Mn (II) Supramolecular Complex," Atmospheric Pollution Research, 10/01, 2019.

[16] M. Pyrc, M. Gruca, A. Jamrozik, W. Tutak, and R. Juknelevičius, "An experimental investigation of the performance, emission and combustion stability of compression ignition engine powered by diesel and ammonia solution (NH4OH)," International Journal of Engine Research, vol. 22, no. 8, pp. 2639-2653, 2021/08/01, 2020.

A. Yapicioglu, and I. Dincer, "Experimental investigation and evaluation of using ammonia and gasoline fuel blends for power generators," Applied Thermal Engineering, vol. 154, pp. 1-8, 2019.

M. ElKelawy, A. El-Shenawy, H. A. E. Mohamad, and S. Abd Al Monem, "Experimental Investigation on Spray Characteristics of Waste Cooking Oil Biodiesel/Diesel Blends at Different Injection Parameters," Journal of Engineering Research, vol. 3, no. December, pp. 29-34, 2019. 
[19] M. F. Ezzat, and I. Dincer, "Comparative assessments of two integrated systems with/without fuel cells utilizing liquefied ammonia as a fuel for vehicular applications," International Journal of Hydrogen Energy, vol. 43, no. 9, pp. 4597-4608, 2018/03/01/, 2018.

[20] A. E. Kabeel, E. A. ElShenawy, M. Elkelawy, H. Alm ElDin Mohamad, and M. M. Elshanshoury, "Numerical Investigation of Combustion in HCCI Diesel Engine Fuelled with Biodiesel Blends," Journal of Engineering Research, vol. 3, no. September, pp. 1-10, 2019.

[21] M. F. Ezzat, and I. Dincer, "Development and assessment of a new hybrid vehicle with ammonia and hydrogen," Applied Energy, vol. 219, pp. 226-239, 2018/06/01/, 2018

[22] M. Ezzat, and I. Dincer, "Exergoeconomic analysis and optimization of a new hybrid fuel cell vehicle," International Journal of Hydrogen Energy, vol. 45, no. 9, pp. 5734-5744, 2020/02/19/, 2020.

[23] A. Yapicioglu, and I. Dincer, "Performance assesment of hydrogen and ammonia combustion with various fuels for power generators," International Journal of Hydrogen Energy, vol. 43, no. 45, pp. 21037-21048, 2018.

[24] S. O. Haputhanthri, T. T. Maxwell, J. Fleming, and C. Austin, "Ammonia and gasoline fuel blends for spark ignited internal combustion engines," Journal of Energy Resources Technology, Transactions of the ASME, vol. 137, no. 6, 2015.

[25] S. O. Haputhanthri, J. Fleming, T. T. Maxwell, and C. Austin, "Ammonia and gasoline fuel blends for internal combustion engines."

[26] S. K. Mahla, V. Singla, S. S. Sandhu, and A. Dhir, "Studies on biogas-fuelled compression ignition engine under dual fuel mode," Environmental Science and Pollution Research, vol. 25, no. 10, pp. 9722-9729, 2018.

[27] C. Enweremadu, and H. Rutto, "Combustion, emission and engine performance characteristics of used cooking oil biodiesel-A review," Renewable and Sustainable Energy Reviews, vol. 14, no. 9, pp. 2863-2873, 2010.

[28] Z. Şahin, M. Tuti, and O. Durgun, "Experimental investigation of the effects of water adding to the intake air on the engine performance and exhaust emissions in a DI automotive diesel engine," Fuel, vol. 115, pp. 884-895, 2014.

[29] K. H. Ryu, G. Zacharakis-Jutz, and S.-C. Kong, Effects of Fuel Compositions on Diesel Engine Performance Using Ammonia-DME Mixtures, 0148-7191, SAE Technical Paper, 2013.

[30] M. Pyrc, M. Gruca, A. Jamrozik, W. Tutak, and R. Juknelevičius, "An experimental investigation of the performance, emission and combustion stability of compression ignition engine powered by diesel and ammonia solution (NH4OH)," International Journal of Engine Research, pp. $1468087420940942,2020$.

[31] S. O. Haputhanthri, T. T. Maxwell, J. Fleming, and C. Austin, "Ammonia and gasoline fuel blends for spark ignited internal combustion engines," Journal of Energy Resources Technology, vol. 137, no. 6, 2015.

[32] E. G. Giakoumis, C. D. Rakopoulos, A. M. Dimaratos, and D. C. Rakopoulos, "Exhaust emissions with ethanol or n-butanol diesel fuel blends during transient operation: A review," Renewable and Sustainable Energy Reviews, vol. 17, pp. 170-190, 2013

[33] J. Warnatz, U. Maas, R. W. Dibble, and J. Warnatz, Combustion: Springer, 2006. 